\title{
VARIATIONS IN EXPERIENCE OF SOCIAL SUPPORT AND PHYSICAL HEALTH AMONG ADULT RESIDENTS OF POLAND IN URBAN VERSUS RURAL AREAS
}

\author{
Bożena Moskalewicz', Pawet Goryński', Jakub Stokwiszewski', Jacek Moskalewicz², \\ Andrzej Kiejna ${ }^{3}$, Bogdan Wojtyniak ${ }^{l}$
}
${ }^{1}$ National Institute of Public Health - National Institute of Hygiene, 24 Chocimska str.,Warsaw, Poland
${ }^{2}$ Institute of Psychiatry and Neurology, 9 Sobieskiego str., Warsaw, Poland
${ }^{3}$ University of Lower Silesia, 55 Strzegomska str., Wroclaw, Poland

\begin{abstract}
Background. A study reveals - against to common beliefs -less support between rural area residents in comparison to town-dwellers and significantly higher support for healthy, not for poor health research participants.

Objectives. The aim of our paper was comparing support from spouse/partner, relatives, friends and strangers among people with good and ill physical health. A next purpose was to find differences of social support and experience of social undermining in urban and rural residential settings.

Material and methods. The study "Epidemiology of Mental Disorders and Access to Mental Health Care, EZOP Poland" was carried out on random sample of 24000 of Poland residents and a 50,4\% response rate, 10081 computerassisted personal interviews. Of those respondents, 4000 constituted a sub-sample asked to complete the social networks and support section of the questionnaire. Data were analyzed by age, gender, residential setting and marital status for statistically significant differences in the percentage of functional and structural social support being reported, using the chi-squared test with a significance level of 0.05 used to reject the null hypothesis $\left(\mathrm{H}_{0}=\right.$ lack of relationship between variables).

Results. A majority of respondents maintain that in difficult life situations, family and a close network of friends and acquaintances make it possible to openly discuss problems and obtain help. However, respondents who rate their health as "poor" or "very poor" significantly less often than healthy individuals experience support coming from their relatives, friends, or strangers.

In comparison to urban areas, the extent of social support in rural areas is significantly limited. The rural setting offers less support and even less opportunities for interaction with relatives, friends, acquaintances and strangers. Negative social factors- low levels of trust, isolation from friends and family, lack of a social life, lack of a helpful neighborhood - are conditions significantly more often found in the countryside than in urban areas.

Conclusions. Results obtained from the EZOP study shows that amount of social support received is higher in urban areas and among those who enjoy better physical health.
\end{abstract}

Key words: relatives and friends support; residential setting; support and health; health status differences; gender differences; social undermining; cultural determinants.

\section{STRESZCZENIE}

Wprowadzenie. Praca odkrywa niezgodną z powszechnymi przekonaniami prawdę, że wieś jest mniej przyjaznym środowiskiem dla swoich mieszkańców niż miasto, a chorzy ludzie, najbardziej potrzebujący wsparcia, otrzymują go znacząco mniej niż zdrowi.

Cel. Celem niniejszej pracy jest porównanie wsparcia, jakie uzyskują osoby w dobrym i złym stanie zdrowia ze strony współmałżonka (partnera), rodziny, przyjaciół i obcych. Kolejnym celem jest ocena różnicy w uzyskiwanym wsparciu, a także przejawach zaprzeczenia wsparcia przez mieszkańców miast i wsi.

Material i metody. Badanie „Epidemiologia zaburzeń psychiatrycznych i dostęp do psychiatrycznej opieki zdrowotnej - EZOP Polska" zostało zrealizowane na próbie losowej 24 tysięcy mieszkańców Polski. Przy 50,4\% poziomie realizacji wywiadów przeprowadzono 10081 wywiadów indywidualnych wspomaganych komputerowo. Następnie

Corresponding author: Bożena Moskalewicz, PhD, Narodowy Instytut Zdrowia Publicznego - Państwowy Zakład Higieny, 24 Chocimska str., 00-791Warsaw, Poland, mobile+48 502222 843, e-mail: bmoskalewicz@pzh.gov.pl

(C) Copyright by the National Institute of Public Health - National Institute of Hygiene 
wyodrębniono 4000 respondentów, którzy odpowiedzieli na pytania o relacje społeczne i wsparcie społeczne. W analizie uwzględniono podział według wieku, płci, środowiska zamieszkania i stanu cywilnego. Ustalono istotne statystycznie różnice w uzyskiwanym wsparciu strukturalnym i funkcjonalnym przy zastosowaniu testu chi-kwadrat, zakładając poziom ufności 0,05 do odrzucenia hipotezy zerowej (H0 = brak związku między zmiennymi).

Wyniki. Większość respondentów utrzymuje, że rodzina oraz krąg bliskich przyjaciół i znajomych - w trudnych sytuacjach życiowych - stwarza warunki do otwartego omówienia problemu i otrzymania pomocy. Niemniej respondenci, którzy oceniają swoje zdrowie jako „złe” i „bardzo złe” istotnie rzadziej doświadczają wsparcia, niż osoby zdrowe. Zakres wsparcia społecznego na terenach wiejskich jest znacząco ograniczony w porównaniu ze wsparciem wśród mieszkańców miast. W środowisku wiejskim stwierdzamy mniej wsparcia, a nawet mniej możliwości spotkania z członkami rodziny, przyjaciółmi, znajomymi lub obcymi. Również na wsi istotnie częściej niż na terenach zurbanizowanych obserwujemy działanie takich negatywnych czynników jak niski poziom zaufania społecznego, izolację wobec rodziny i przyjaciół, brak życia towarzyskiego, oraz brak pomocnego sąsiedztwa.

Wnioski. Wyniki badania EZOP wskazują, że zakres otrzymywanego wsparcia społecznego jest istotnie wyższy w środowiskach miejskich, oraz wśród osób cieszących się lepszym zdrowiem fizycznym.

Słowa kluczowe: wsparcie $w$ rodzinie; wsparcie przyjaciót; miejsce zamieszkania; wsparcie społeczne $i$ zdrowie; różnice w stanie zdrowia; podziat wedtug ptci; zaprzeczenia wsparcia; determinanty kulturowe.

\section{INTRODUCTION}

Susceptibility to illness, as well as the effects of illness and treatment outcomes may depend on the quality of social support provided by those nearest to the patient [1-8]. The study "Epidemiology of Mental Disorders and Access to Mental Health Care, EZOP - Poland" was carried out from 2010 to 2011 by the Institute of Psychiatry and Neurology (IPiN) in Warsaw, together with the National Institute of Public Health (NIZP-PZH) in Warsaw and the Psychiatry Department and Clinic at Wrocław Medical University [9]. Results obtained from the EZOP study shows that amount of social support received is higher in urban areas, for women and among those who enjoy better physical health.

The lengthy World Health Organization's Composite International Diagnostic Interview (WHO-CIDI) questionnaire, translated into Polish and used for the study as the EZOP questionnaire, contained a section pertaining to social networks and support from family and close friends. The following were identified and studied as sources of social support in the EZOP Project: meetings and (phone) conversations engendering a sense of belonging - with one's spouse/ committed partner, with relatives (interactions and conversations), with friends and acquaintances (interactions and conversations), and with strangers/ others (conversations). If the respondent had a serious problem or needed to talk to someone, he or she was asked how much she/he can rely on the support of a) spouse/partner, b) relatives not living with him/her, c) friends/acquaintances, d) other people. Questions asking the respondents to self-rate their symptoms and condition of physical health were used to gauge the state of their health.
Our paper aims to answer the following research questions:

Q1: Is the degree of social support in the two identified residential settings (urban vs. rural) the same or different?

Q2: Does social undermining occur in both settings equally often? Does the residential setting influence how social support is experienced or perceived? What about the experience of social undermining or denial of social support in the two settings [10]?

Q3: Who receives less social support from their spouse/partner, relatives, friends and strangers - those who are well or those who are ill in urban and rural areas?

\section{MATERIALS AND METHODS}

Given a random sample of 24000 of Poland's residents, and a 50.4\% response rate, 10081 computerassisted personal interviews were carried out. Of those respondents, 4000 constitute a sub-sample asked to complete the social networks and support section of the questionnaire. The sub-sample consists in all respondents with mental disorders as well as their randomly selected counterparts.

The analysis presented in this paper is focused on functional and structural social support, based on answers that were given by 3999 respondents of which $61.1 \%$ lived in the urban areas while $38.9 \%$ in rural areas.

Measures of structural social support, included answers to questions about the frequency of interactions with acquaintances, friends, family and spouse/partner, as well as demographic variables: the respondent's residential setting, gender, education completed and marital status. 
Measures of functional social support on the other hand, include how much the respondent can rely on help from family, friends and acquaintances in case of problems, how open he or she can be with them and how often he or she has conflicts or argues with them (reverse-coded) [11]. An example of such a reversecoded question was: Not including your (husband/wife, partner) how often do your relatives argue with you (often, sometimes, rarely, or never)? Another question, structured the same way, was asked about relatives placing too many demands on the respondent. Two analogous questions were asked about disagreements with and demands made by friends (see Annex).

Data were analyzed by age, gender, residential setting and marital status for statistically significant differences in the percentage of functional and structural social support being reported, using the chisquared test with a significance level of 0.05 used to reject the null hypothesis $\left(\mathrm{H}_{0}=\right.$ lack of relationship between variables).

\section{RESULTS AND DISCUSSION}

\section{SOCIAL SUPPORT ACCORDING TO RESIDENTIAL SETTING}

As the tables illustrate, residents of rural areas receive significantly less support than residents of urban areas.

Table 1. Structural social support: Frequent interactions (conversations, meetings, phone calls) with the following people

\begin{tabular}{|c|c|c|c|c|c|c|c|c|c|}
\hline \multirow{3}{*}{ Who: } & \multicolumn{3}{|c|}{ Urban } & \multicolumn{3}{|c|}{ Rural } & \multicolumn{3}{|c|}{ Total } \\
\hline & \multirow{2}{*}{$\begin{array}{c}\text { Percentages } \\
71.7\end{array}$} & \multicolumn{2}{|c|}{$95 \% C I$} & \multirow{2}{*}{$\begin{array}{c}\text { Percentages } \\
76.5\end{array}$} & \multicolumn{2}{|c|}{$95 \% C I$} & \multirow{2}{*}{$\begin{array}{c}\text { Percentages } \\
73.6\end{array}$} & \multicolumn{2}{|c|}{$95 \% C I$} \\
\hline & & 69.1 & 74.2 & & 73.4 & 79.4 & & 71.6 & 75.5 \\
\hline Relatives living separately & 81.6 & 81.5 & 84.9 & 78.6 & 78.8 & 83.3 & 80.4 & 81.1 & 83.8 \\
\hline Friends and acquaintances & 88.1 & 86.5 & 89.5 & 82.9 & 80.6 & 85.0 & 86.1 & 84.8 & 87.3 \\
\hline Others & 55.5 & 53.2 & 57.7 & 52.4 & 49.5 & 55.3 & 54.3 & 52.5 & 56.1 \\
\hline
\end{tabular}

Table 2. Functional social support: Trust and degree of perceived help

\begin{tabular}{|c|c|c|c|c|c|c|c|c|c|}
\hline \multirow{3}{*}{ Support: } & \multicolumn{3}{|c|}{ Urban } & \multicolumn{3}{|c|}{ Rural } & \multicolumn{3}{|c|}{ Total } \\
\hline & \multirow{2}{*}{$\begin{array}{c}\text { Percentages } \\
70.8\end{array}$} & \multicolumn{2}{|c|}{$95 \% C I$} & \multirow{2}{*}{$\begin{array}{c}\text { Percentages } \\
67.0\end{array}$} & \multicolumn{2}{|c|}{$95 \% C I$} & \multirow{2}{*}{$\begin{array}{c}\text { Percentages } \\
69.3\end{array}$} & \multicolumn{2}{|c|}{$95 \% C I$} \\
\hline & & 68.7 & 72.8 & & 64.2 & 69.7 & & 67.7 & 70.9 \\
\hline $\begin{array}{l}\text { Being open with friends and } \\
\text { acquaintances }\end{array}$ & 65.4 & 63.2 & 67.5 & 57.9 & 55.1 & 60.7 & 62.5 & 60.8 & 64.2 \\
\hline $\begin{array}{l}\text { Perceived help from } \\
\text { relatives }\end{array}$ & 73.4 & 71.4 & 75.4 & 72.2 & 69.5 & 74.7 & 73.0 & 71.3 & 74.5 \\
\hline $\begin{array}{l}\text { Perceived help from friends } \\
\text { and acquaintances }\end{array}$ & 20.3 & 18.5 & 22.2 & 15.0 & 13.1 & 17.1 & 18.2 & 16.9 & 19.7 \\
\hline
\end{tabular}

\section{SOCIAL SUPPORT - STRUCTURAL VARIABLES}

The EZOP study reveals that interactions with friends and acquaintances are more frequent than interactions with relatives who do not live with the respondent. In cities, the frequency of interactions (meetings in person, phone conversations) with acquaintances and friends is significantly higher than in the countryside. However, overall, Poles are more trusting and open towards their relatives than with friends; rural residents being somewhat less open and trusting towards relatives than respondents living in cities.

When in need, in case of a serious problem, respondents indicated that they rely on their family for help [12, 13]. Friends and acquaintances were identified as a source of support four times less often than relatives living in a separate household. Rural residents less frequently expect direct help from friends and acquaintances than respondents living in urban areas [14]. 


\section{SOCIAL SUPPORT - FUNCTIONAL VARIABLES}

Respondents who are equally open with family and friends/acquaintances are as often found in rural areas $(9.6 \%)$ as in urban areas (10.5\%) [15]. Men residing in cities $(8.0 \%)$ reported being able to open up slightly more often in their interactions than their rural counterparts $(7.3 \%)$. Likewise, female urban residents believe they can talk about their problems more often $(12.8 \%)$ than do women living in rural areas $(11.8 \%)$. The highest statistically significant difference in the ability to talk about one's problems was found between men in the countryside (7.3\%) and women living in cities (12.8\%).

One should ask whether respondents who are open towards friends and relatives are also equally open with their spouse or partner. Regardless of where they live, women are significantly more likely to talk openly with their partner/spouse (12.4\%) than are men $(7.7 \%)$. This difference between the sexes is also true concerning conversations with relatives and friends. Women declare a greater willingness than men do to openly discuss their problems [16].

\section{DENIAL OF SOCIAL SUPPORT - CONFLICTS AND EXCESSIVE DEMANDS}

Social undermining, the opposite of social support, is the intentional contestation of somebody's position, which is detrimental to self-esteem, social reputation and others' view of one's ability to maintain positive interpersonal relations [17].

The behavior of one's less-immediate family can be hostile or unfriendly at times. Still, those who live in the countryside report slightly less frequent overt denial of social support on the part of their relatives, when compared to respondents in cities. Rural residents indicate that their relatives argue/have conflicts with them slightly less often than do their counterparts living in urban areas - and this difference borders on being significant.

Table 3. Social undermining among relatives

\begin{tabular}{|c|c|c|c|c|c|c|}
\hline \multicolumn{7}{|c|}{ Q: How often do your relatives argue with you? } \\
\hline \multirow{2}{*}{$\begin{array}{l}\text { Social } \\
\text { undermining: }\end{array}$} & \multicolumn{2}{|c|}{ Urban } & \multicolumn{2}{|c|}{ Rural } & \multicolumn{2}{|c|}{ Total } \\
\hline & Percentages & $95 \% C I$ & Percentages & $95 \% C I$ & Percentages & $95 \% C I$ \\
\hline Rarely, never & 80.7 & $78.9-82.4$ & 83.1 & $80.9-85.2$ & 81.7 & $80.3-83.0$ \\
\hline Often, sometimes & 19.3 & $17.6-21.1$ & 16.9 & $14.8-19.1$ & 18.3 & $17.0-19.7$ \\
\hline
\end{tabular}

Table 4. Social undermining among friends

Q: How often do your friends make too many demands on you?

\begin{tabular}{|l|c|c|c|c|c|c|}
\hline \multirow{2}{*}{$\begin{array}{l}\text { Social } \\
\text { undermining: }\end{array}$} & \multicolumn{2}{c|}{ Urban } & \multicolumn{2}{c|}{ Rural } & \multicolumn{2}{c|}{ Total } \\
\cline { 2 - 8 } & Percentages & $95 \% C I$ & Percentages & $95 \% C I$ & Percentages & $95 \% C I$ \\
\hline Rarely, never & 84.3 & $82.6-85.9$ & 88.1 & $86.1-89.8$ & 85.8 & $84.5-87.0$ \\
\hline Often, sometimes & 15.7 & $14.1-17.4$ & 11.9 & $10.2-13.9$ & 14.2 & $13.0-15.5$ \\
\hline
\end{tabular}

The contrast between urban and rural settings when it comes to being subject to excessive demands of friends is as follows: $16.6 \%$ of respondents in cities compared to only $11.9 \%$ in the countryside report feeling that their friends' demands are excessive. This difference is statistically significant.

\section{SOCIAL SUPPORT AND PHYSICAL HEALTH}

The social support network may play a crucial role in one's ability to cope with a serious illness[18-21]. We investigated whether in case of illness the social network increases or denies its support, and whether this pattern is similar in cities and in the countryside.

\section{Relatives}

Respondents who are ill and live in the country report being isolated from their relatives more often $(24.3 \%)$ than their city-dwelling counterparts $(21.6 \%)$. Similar results were obtained from healthy respondents, with $19.2 \%$ feeling isolated in the country and $16.7 \%$ in cities. 
Respondents who reported that they do not receive help from their relatives constituted $28.1 \%$ of the whole sample. Among those who are ill, the percentage is higher: $35.1 \%$ in the countryside and $35.4 \%$ in urban areas. Thus, regardless of where they live, individuals in worse physical health count on help from relatives less often than do healthy individuals.

Worse physical health is also linked to lower levels of openness and trust towards relatives. 34.1\% of ill respondents said they cannot be open with their relatives, compared to $31.6 \%$ of respondents whose health is satisfactory and $29,3 \%$ of respondents who are in perfect health. Isolation and lack of an open atmosphere among relatives is described by $34.0 \%$ of ill respondents in cities and by $34.2 \%$ in the country. This difference between residential settings is small and statistically insignificant.

About one third of ill respondents in urban areas feel their relatives demand too much from them while a corresponding figure in the countryside is about one fifth.

City residents in poor physical health report conflicts with relatives significantly more often $(26.0 \%)$ while in the countryside only $12.4 \%$ of ill respondents mentioned family conflicts, which is suggestive of a rather agreeable environment.

\section{Friends and acquaintances}

About $15 \%$ of all respondents, regardless of their health status, see their friends' expectations as excessive.

Nearly all healthy residents of urban areas (91.7\%) mentioned frequent contact with their friends [22]. Healthy residents of rural areas maintaining frequent contact with friends and acquaintances constitute $87.8 \%$ of their group, which is less than in urban areas. The percentage of city-dwelling ill respondents maintaining such contacts is lower (80.4\%), compared to even lower percentage of ill rural residents (71.9\%).

$16.7 \%$ of rural residents, who declare being in good health, are likely to receive help from their friends and acquaintances, compared to $13.4 \%$ of those who report that their health is bad. In urban areas, 23.2\% of respondents who identify themselves as healthy count on the help of friends and acquaintances, but only $10.1 \%$ of ill individuals do. This difference is statistically significant.

Among healthy female respondents there is a clear difference depending on the place of residence. $25.5 \%$ of healthy women residing in cities say they can count on the help of friends, compared to only $14.5 \%$ of healthy female residents of rural areas.

The data used in this study reveal statistically significant differences in the situation of respondents, depending on whether they are in good or poor physical health. In general, ill respondents perceive less openness in relations with their friends than do respondents who are healthy, regardless of whether they live in the city or in the country.

\section{Spouse/partner}

Only in urban areas does illness play a role in how often personal problems are discussed with one's spouse or partner [23]. When compared to healthy city residents $(73.7 \%)$, urban residents who are ill significantly less often count on the support of their spouse or partner $(63.9 \%)$.

\section{Someone else}

Poor health tends to significantly reduce trust [24] and the frequency of interactions with strangers and individuals with whom one is less acquainted. In urban areas, $58 \%$ of healthy respondents feel they can talk to strangers about their worries or problems, compared to only $46 \%$ of respondents who are ill. In the countryside, $55 \%$ of healthy respondents reported talking to strangers about their problems, while only $42.8 \%$ of respondents in poor health did the same. All of the above differences are statistically significant.

\section{CONCLUSIONS}

1. A vast majority of respondents maintain that in difficult life situations, family and a close network of friends and acquaintances make it possible to openly discuss problems and obtain help. However, respondents who rate their health as "poor" or "very poor" significantly less often than healthy individuals experience support coming from their relatives, friends, or strangers.

2. In comparison to urban areas, the extent of social support in rural areas is significantly limited. The rural setting offers less support (in terms of functional variables) and even less opportunities for interaction (structural variables) with relatives, friends, acquaintances and strangers. Negative social factors - low levels of trust, isolation from friends and family, lack of a social life, lack of a helpful neighborhood - are conditions significantly more often found in the countryside than in urban areas.

3. Female respondents more frequently perceive that they are the recipients of social support. Likewise, respondents who are in a committed relationship, be it with a spouse or partner, also report receiving more support.

\section{Funding / Acknowledgements}

The Authors disclosed receipt of the following financial support for the research: EAA Financial Mechanism, grant number Pl 0256 and the Polish Ministry of Health. 


\section{ANNEX SURVEY QUESTIONS}

How often do you talk on the phone or get together with relatives who do not live withyou-mostevery day, a few times a week, a few times a month, about once a month, or less than once a month?

MOST EVERY DAY
A FEW TIMES A WEEK $\ldots \ldots \ldots \ldots \ldots \ldots \ldots \ldots \ldots \ldots \ldots \ldots \ldots \ldots \ldots \ldots \ldots$
A FEW TIMES A MONTH

How much can you rely on relatives who do not live with you for help if you have a serious problem - $\underline{\text { a lot, }}$ some, a little, or not at all?

A LOT

How much can you open up to relatives who do not live with you if you need to talk about your worries - (a lot, some, a little, or not at all)?

A LOT

How often do your relatives make too many demands on you - often, sometimes, rarely, or never?

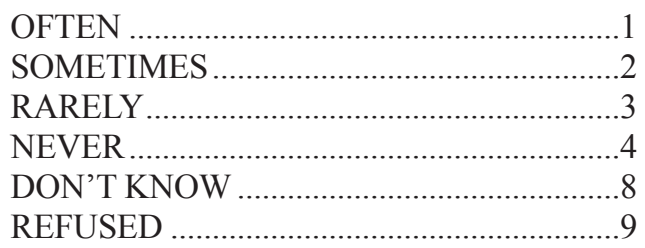

How often do your relatives argue with you - (often, sometimes, rarely, or never)?

OFTEN
SOMETIMES
RARELY
NEVER
DON'T KNOW
REFUSED

How often do you talk on the phone or get together with friends- most every day, a few times a week, a few times a month, about once a month, or less than once a month?
How much can you rely on your friends for help if you have a serious problem - $\underline{\text { a lot, }}$ some, a little, or not at all
How much can you open up to your friends if you need to talk about your worries - (a lot, some, a little, or not at all)?

How often do your friends make too many demands on you often, sometimes, rarely, or never?

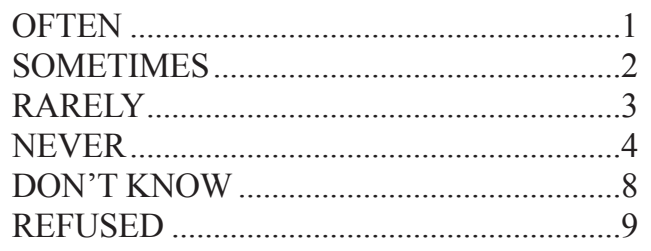

How often do your friends argue with you - (often, sometimes, rarely, or never)?

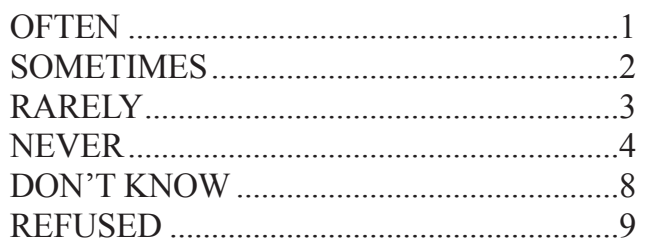


When you have a problem or worry, how often do you let your (husband/wife/partner) know about it - always, most of the time, sometimes, rarely, or never?

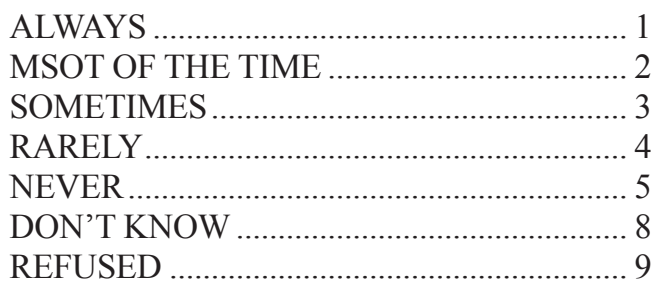

\section{REFERENCES}

1. Taylor SE.: Social Support: A Review. In Friedman HS (Ed.) The Oxford handbook of health psychology. Oxford University Press 2011 (189-215)

2. Perkins JM, Subramanian SV, Christakis NA.: Social networks and health. A systematic review of sociocentric network studies. Soc Science and Medicine 2014; XXX:1-19

3. Sztompka P.: Kapitał społeczny. Teoria przestrzeni międzyludzkiej. [Social Capital. Theory of Relational Space] Kraków Znak 2016

4. Kim HS, Sherman DK, Taylor SE.: Culture and Social Support. American Psychologist 2008;63(6): 518-526

5. Hyуррӓ MT, Mäki J.: Social participation and health in a community rich in stock of social capital. Scand J of Public Health 2003; 18 (6): 770-779

6. Reblin M, Uchino BN.: Social and Emotional Support and its Implication for Health Curr Opin Psychiatry. 2008; 21(2): 201-205. doi:10.1097/YCO.0b013e3282f3ad89.

7. Ali T, Nilsson CJ, Weuve J., Rajan KB, Mandes de Leon $C F$.: Effect of social network diversity on mortality, cognition and physical function of the elderly a longitudinal analysis of the Chicago Health and Aging Project (CHAP) J Epidemiol Community Health 2018; 0: 1-7

8. Zigante $V .:$ Informal Care in Europe. Exploring Formalisation, Availability and Ouality. European Commission Report 2018.

9. Moskalewicz J, Kiejna A, Wojtyniak B. (eds): Kondycja psychiczna mieszkańców Polski. [The State of Mental Health Among Residents of Poland]. Warszawa 2012

10. Hofferth SL, Iceland J.: Social capital in rural and urban communities. Rural Sociol. 2011; 63(4): 574-598.

11. Strighini $S$, Berkman L, Dugravot $A$ et al.: Socioeconomic Status, Structural and Functional Measures of Social Support, and Mortality. The British Whitehall II Cohort Study, 1985-2009. Am J Epidemiol. 2012;175(12):1275-1283.

12. Agar B, Carrino L, Orso C, Passini G.: Vulnerability and Long-term Care in Europe: An Economic Perspective. Springer 2017

13. Viana MC, Gruber MJ, Shahly $V$ et al.: Family burden related to mental and physical illness in the world: Results from the WHO World Mental Health (WMH) Surveys. Braz J Psychiatry 2013; 35(2):115-25
When you have a problem or worry, how often do you let someone (else) know about it - always, most of the time, sometimes, rarely, or never?

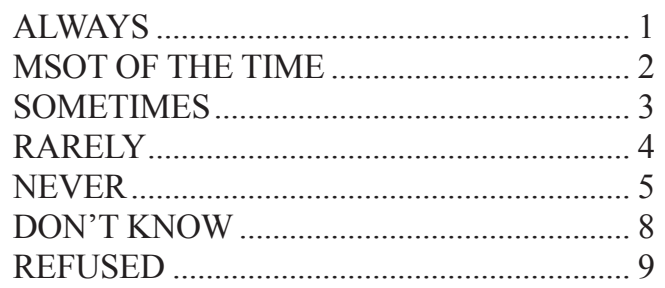

14. Czapiński J, Panek T. (eds): Diagnoza Społeczna. Warunki i Jakość Życia Polaków. Raport [Social Diagnosis. Circumstances and Quality of Life of Polish Citizens. Research Report] Warszawa 2011: 218.

15. Umberson D.: Social Relationships and Health Behavior. Annu Rev Sociol. 2010 Aug1;36:139-157.

16. Taylor SE, Klein LC, Lewis BP et al.: Biobehavioral Responses to Stress in Females: Tend-and-Befriend, not Fight-or-Flight. Psychological Review 2000; 107(3):411-429.

17. Burg MM, Seeman TE.: Families and Health: The negative side of social Ties/ The role of the family as a source of stress [review of the literature] Annals of Behavioral Medicine 1994; 16(2):109-115.

18. House JS, Landis KR, Umberson D.: Social Relationships and Health. Science 1988; 241:540-545.

19. Tobiasz-Adamczyk B., Zawisza K.: Urban-rural differences in social capital in relation to self-rated health and subjective well-being in older residents of six regions in Poland. Ann Agric Envinron Med. 2017;24(2): 162-170.

20. Uchino B.N.: Social Support and Health. A review of psychological processes potentially underlying links to disease outcomes. J Behav Med 2006; 29 (4):377-387

21. Uchino, B.N.: Understanding the Links Between Social Support and Physical Health: A Life-Span Perspective With Emphasis on the Separability of Perceived and Received Support. Perspect Psychol Sci. 2009; 4(3):236-55

22. Mulvaney-Day NE., Alegria M, Sribney W.: Social cohesion, social support and health among Latinos in the United States. Soc Science Med 2007; 64: 477-495

23. Nissen NK, Jonsdottir M, Spindler H. Zwisler AO.: Resistance to change: Role of relationship and communal coping for coronary heart disease patients and their partners in making lifestyle changes Scand J Public Health 2018 Aug;46(6):659-666. doi: $10.1177 / 1403494818756562$

24. European Quality of Life Survey 2016: Quality of life, quality of public services and quality of society. Publications Office of the European Union, Luxembourg 2017

Received: 10.10.2019

Accepted: 12.11.2019

This article is available in Open Access model and licensed under a Creative Commons Attribution-Non Commercial 3.0.Poland License (CC-BY-NC) available at: http://creativecommons.org/licenses/by-nc/3.0/pl/deed.en 